\author{
Zh.O. Tattimbetova ${ }^{1}$ (iD , S.K. Mizanbekov ${ }^{1}$ (iD , K.N. Galay ${ }^{2}$ (iD \\ ${ }^{1}$ Al-Farabi Kazakh national university, Kazakhstan, Almaty, \\ e-mail: zhibek0709@gmail.com, e-mail: Serik_mizanbekov@mail.ru, \\ ${ }^{2}$ People’s Friendship University of Russia, Moskow, Russia, e-mail: galay karina@mail.ru
}

\title{
COMPARATIVE ANALYSIS OF LITERARY TEXT AS A TENDENCY IN MODERN SCHOOL EDUCATION
}

The article is devoted to the actual issue of studying literature at school through the prism of theory and methods of comparative studies. The most important matter is the overall application of the comparative method theory (comparatism) in literature lessons and its widespread use in practice. The authors emphasize that literary comparative studies are one of the modern directions, which is focused on ensuring the cultural identification of the student and the advancement of his or her critical independence. It also focuses on ideas about the historical and literary process and the ways of development of literature. The potential of such comparative methods as: comparing literary characters of same work, comparing its episodes, employing comparative analysis to trace the influence of the landscape on the mindset or spirits of the character, as well as comparing various authors belonging to the same era but coming from different cultural and national backgrounds are considered that allows students to achieve a complete understanding of the work's ideas, and its interpretation, thus revealing the general laws of a unitary literary and cultural process. We can identify a working classification of comparative study of different kinds of literature. Recommendations for the types of exercises are given: speech exercises for teaching written messages; written speech exercises for working with printed text; comparative tests after reading the work; a test based on the character, work, author, literary direction; a proposal to interpret the work or work of the author as a whole (photo, video- collage) to the work or presentation in the form of historical and / or cultural commentary on the selected topic, etc.

Key words: comparative studies, teaching literature, text analysis, comparatism, comparative method.

\author{
Ж.О. Таттимбетова ${ }^{1}$, С.К. Мизанбеков ${ }^{1}$, К.Н. Галай ${ }^{2}$ \\ 'Ә^-Фараби атындағы Қазақ ұлттық университеті, Қазақстан, Алматы қ., \\ Ресей Халықтар Аостығы Университеті, Ресей, Мәскеу қ., \\ e-mail: zhibek0709@gmail.com, Serik_mizanbekov@mail.ru galay_karina@mail.ru \\ Қазіргі мектептегі бікім берудегі тенденция ретінде \\ көркем мәтінді салыстырмалы талдау
}

Мақала компаративистиканың теориясы мен әдістерінің призмасы арқылы мектептегі әдебиетті оқытудың өзекті мәселесіне арналған. Әдебиет сабақтарында салыстырмалы әдісті (компаративистиканы) қолдану теориясын жинақтау және оны тәжірибеде кеңінен қолдану аса маңызды болып табылады. Авторлар әдебиеттану компаративистикасы оқушының мәдени идентификациясын қамтамасыз етуге, сыни дербестікті дамытуға және тарихи-әдеби процесс туралы және әдебиеттің даму жолдары туралы түсініктерді дамытуға бағытталған қазіргі заманғы бағыттардың бірі болып табылатынын атап көрсетеді. Компаративистиканың бір шығарманың кейіпкерлерін салыстыру, эпизодтарды салыстыру, кейіпкердің көңіл-күйімен немесе мінезімен байланысты пейзаж бейнесін салыстырмалы та^дау, сондай-ақ бір дәуірдің әр түрлі авторларын салыстыру, бірақ әр түрлі мәдениеттер (елдер) сияқты тәсілдерінің әлеуетті мүмкіндіктері қарастырылды, бұл білім алушыларға шығарманың илеясын толық түсінуге, оның түсіндірілуіне, бірыңғай әдеби және мәдени процестің жалпы заңдылықтарын анықтауға мүмкіндік береді. Авторлар әдебиеттің түрлерінің салыстырмалы оқытудың жұмыстық жіктемесін ұсынады. Жаттығу типтері: жазбаша хабарламаларды оқытуға арналған тілдік жаттығулар; баспа мәтіндермен жұмыс жасауға арналған жазбаша тілдік жаттығулар; жұмысты оқығаннан кейінгі салыстырмалы тестер; жұмыстың сипаты, автор, әдеби бағыт негізіндегі тест; таңдалған тақырып және т.б бойынша автордың жұмысы немесе шығармасы (фото, бейне-комлаж) туындыға немесе тұсаукесерге арналған тарихи және/ немесе мәдени тұтастықтағы интерпретациялық, түсінік бойынша ұсыныстар беріледі.

Түйін сөздер: салыстырмалы зерттеулер, оқу әдебиеті, мәтінді талдау, салыстыру әдісі. 


\author{
Ж.О. Таттимбетова' ${ }^{1}$ С.К. Мизанбеков ${ }^{1}$, К.Н. Галай², \\ 'Казахский национальный университет им. аль-Фараби, Казахстан, г. Алматы, \\ e-mail: zhibek0709@gmail.com, Serik mizanbekov@mail.ru \\ ${ }^{2}$ Россйский университет Аружбы народов, г. Москва, Россия, e-mail: galay_karina@mail.ru \\ Сравнительный анализ художественного текста \\ как тенденция в современном школьном образовании
}

\begin{abstract}
Статья посвящена актуальному вопросу изучения литературы в школе через призму теории и методов сравнительного исследования. Наиболее важным вопросом является общее применение теории сравнительного метода (компаративизма) на уроках литературы и ее широкое применение на практике. Авторы подчеркивают, что митературоведение является одним из современных направлений, которое ориентировано на обеспечение культурной идентификации студента и развитие его критической самостоятельности. Она также фокусируется на представлениях об историко-литературном процессе и путях развития китературы. Рассматриваются возможности таких сравнительных методов, как: сравнение китературных персонажей одного и того же произведения, сравнениеегоэпизодов, использованиесравнительногоанализадляпрослеживания влияния пейзажа на образ мыслей или дух персонажа, а также сравнение различных авторов, принадлежащих к одной эпохе, но происходящих из разных культурных и национальных слоев, что позволяет студентам достичь полного понимания идей произведения и его интерпретации, раскрывая тем самым общие закономерности единого китературно-культурного процесса. Авторами предложена рабочая классификация сравнительного изучения различных виАов митературы. Изложены рекомендации по типы упражнений: речевые упражнения Аля обучения письменным сообщениям; письменные речевые упражнения для работы с печатным текстом; сравнительные тесты после прочтения работы; тест на основе характера, работы, автора, литературного направления; предложение интерпретации произведения или работы автора в целом (фото, видео-комлаж) к произведению или презентации в виде исторического и / или культурологического комментария по выбранной теме и др.
\end{abstract}

Ключевые слова: сравнительное исследование, учебная литература, анализ текста, компаративизм, сравнительный метоА.

\section{Introduction}

The purpose of this work is to develop a methodological model and specific methodological recommendations for the use of comparative analysis in the study of literature in high schools.

Materials and methods of reseach

The methodological basis of the study was formed by the classical works of F.I. Buslaev, V.I. Vodovozov, V.Y. Stoyunin, V.P, Ostrogorsky, V.P. Sheremetevsky, C.P. Baltalon, N.M. Sokolov, M.A. Rybnikova, V.V. Golubkov et al. An important role in the formation of the research concept was played by the works of literary critics (A.N. Veselovsky, M.M. Bakhtin, Yu.N. Tynyanov, S.S. Averintsev, Yu.M. Lotman, G.A. Gukovsky, E.A. Meletinsky and others). ), devoted to the problems of succession bonds in the development of literature, as well as the work of psychologists, philosophers, methodologists and educators, covering the problem of systemic-associative relations in learning (P.Y. Galperin, L.S. Vygotsky, A.N. Leontiev, D.A. Leontiev, V.F. Palamarchuk, S.M. Bondarenko and others). In the second half of the XX century the methodology of comparative analysis was reflected in the works of N.I. Kudryashov, M.G. Kachurin, G.I. Belenky, L.V. Todorov, V.G. Marantzman, O.Y. Bogdanova and other methodologists.
The strategy inherent in the SMSE (State Mandatory Standard of Education) assumes intensification of the whole literature teaching process, the updating of educational and methodical materials to modern requirements of language didactics, reorganization of teachers to a special approach in the arrangement of the educational process providing the maximum rise of intellectual, thought and communicative activity of students, development of their ability to independently and productively apply the received knowledge in various activity fields.

A comparative literature study is one of the modern directions which is focused on providing cultural identification of the student, establishment of spiritual connection between them and their people, strengthening the feeling of belonging to the national culture, acquisition of its values.

As it is known, a methodical practice usually uses those techniques that can ensure the integrity of perception of the fiction text, its comprehensive interpretation, thus, when studying a school course of literature it is necessary to emphasize that no single writer can not exist separately, as the whole literature, in fact, is permeated by various ties of mutual influence. Literature is, in essence, a dialogue between writer and reader, which is always on the move, in the interconnectedness of literary and historical processes. 
Comparative philology, also known as comparative linguistics and comparative literature is one of the fundamental directions in philology, and it began to form as a science in the middle of the XIX century. One of the founders was Johann Gottfried Herder (1744 - 1803), who, after Johann Joachim Winkelmann (1717 - 1768), began to talk about comparative poetics. It was J.G. Herder who began to consider Goethe's work in the context of world literature and culture. It can be assumed that the manifesto of Comparative linguistics is the preface by Theodor Benfey (1809 - 1881) to the German translation of "Panchatantra", published in 1859 , in which he spoke about borrowing, the migration of ideas, images, and plots. However, it was Russian literary critic Vissarion Belinsky in 1834, who wrote: "If two writers write in the same way and have any resemblance to each other, the best way they can be evaluated in relation to each other, is by exhibiting parallel places: this is the best touchstone" (Belinskiy, 1959: 84). Despite this, F. Buslaev (1818 - 1897) and A. Veselovsky (1838 1906) are considered in Russia and in the post-Soviet space to be the initiators of comparative philology.

In the second half of the XIX century, an active phase of development of comparative literature is observed, as research becomes deeper and more diverse, and comparative philology becomes an independent branch. For instance, in 1886 English literary critic Hutcheson Macaulay Posnett published his book "Comparative Literature ", which investigates the materials of world literature in connection with social processes. German scientist Max Koch published a special "Journal of Comparative Literature History", which existed until 1910. A significant contribution to the development of this direction of literary studies was made by the French researcher F. Brunethiere, who at the end of the XIX century spoke about the need for a wide coverage of the phenomena of world literature.

\section{Results}

The theory of applying the method of comparison developed by N. Sobolev already back in 1976 in his work «The method of comparative analysis of artistic works at school. This is one of the most relevant works to date, which helps methodologists and teachers to build a comparative study of literature. Acceptance of comparison was in the arsenal of the largest methodologists of the XIX century. The merit of using the comparative method in the lessons of literature belongs to V. Vodovozov. He proposed to conduct comparisons on thematic, genre and language features. Comparative analysis of two works or passages was a favorite technique in the practice of V. Stoynin, who compared thematically similar works. Further development of comparison as a method of analysis is found in the works of V. Ostrogorsky, who suggested comparing statements of two critics about one work.

The great importance of the method of comparison is noted in the works of M.Rybnikova, N.Korst, V.Nikolsky, N.Kudryashev and others. For example, in the development of M. Rybnikova's lessons, a number of comparisons are given. «The Tale of the Dead Princess and the Seven Knights» by Pushkin is compared with the folk tale «Father Frost», a description of the autumn forest at Pushkin with a description of the autumn field at Tyutchev. V.Nikolsky in his book «Teaching Literature in High School» widely uses parallels between literature and other art forms, comparison of heroes, critical articles, original and translation. Professor G.Gukovsky in his fundamental work «Study of Literature at School» noted that comparisons have meaning and significance only in the proximity of creative systems and methods. In high school, the scientist emphasized, comparisons acquire a great historical completeness, as not only heroes are compared, but also «types of consciousness».

It is recommended to use in their methodological works N.Moldavskaya, N.Meshcheriakova, Z.Rez, L.Aizerman and a number of other methodologists. Today, O. Bogdanova, V. Marantsman, V. Certov, N. Demidova and others are working fruitfully on questions and problems of methodology of teaching literature. All leading modern methodologists note the effectiveness of using the method of comparison in literature lessons.

\section{Discussions}

Further updating of comparative literature methods took place through the works of French scientists: F. Baldensperger (1871-1958), Paul Hazard (1878-1944), Paul van Tighem (1871-1948), who divided the literature into "influencing" and "perceiving", although they reduced comparative philology to the analysis of foreign influences. Later, the works of René Wellek (1903 - 1995) and René Étiemble (1909 - 2002) contributed to the expansion of the objects of comparative literature: they wrote about the necessity of analysis of literary phenomena not united by direct contact or genetic ties.

The look into the history of language didactic studies in the post-Soviet space shows that the activation of comparative philology begins in the 70 s of XX century with the works of such scientists as V. Zhirmunsky (1891 - 1971), N. Konrad 
(1891 - 1970), I. Neupokoeva (1917 - 1977), M. Khrapchenko (1904 - 1986), N. Kravtsov (1906 - 1980) and others, who suggested comparing not only the literature of similar historical communities but also literatures that in many senses stand apart from each other. This aspect is most fully reflected in the modern definition of comparative linguistics.

It should be noted that from the methodological point of view, the use of comparative linguistics in the study of literature at school is not new. The use of comparison, common understanding of comparative research methods was in the toolkit of methodologists back in the XIX century. For instance, V. Vodovozov (1825-1886) theoretically justified the use of a comparative method (comparative philology) in the lessons of literature and widely used it in practice. He proposed to "find the living side" of the subject through opposites and comparisons and to indicate the characteristic properties of the subject, be it letters, numbers or works. For example, he suggested comparing Pushkin's "Song about wise Oleg" with annalistic stories, and Krylov's fables with folk tales, Gogol's "Overcoat" with his own "Diary of a Madman".

A well-known pedagogue and publicist $\mathrm{V}$. Stoynin (1826-1888) also said that the comparative method is one of the progressive methods of teaching literature at school, the "comparative method" was a favorite method of the scientist: "... explaining the characters, you can compare the image of the same character with different writers or a different flow of the same passion in different personalities. Having reached the explanation of the essence of the epic story, it is possible to compare Gogol's Taras Bulba with the historical tale "Bogdan Khmelnitsky" by Kostomarov about the same epoch and from here it is easy to distinguish epic poetry and history... and also from here by means of observations it is easy to reach the definition of the difference between prose and poetry, and hence to find out the essence of both" (Stoyunin, 1908: 13).

Comparison as a method of analysis is also used by V. Ostrogorsky (1840-1902), who introduced the study of literature at a secondary school and the careful examination of criticism and suggests comparing statements of different critics about one literary work. He also suggested comparing literature with other arts, particularly painting and theater. He spoke of the need to develop independence in pupils when it comes to critical thinking. Also, in this regard, he compared several works on the same subject so that the pupil could (and, most importantly, wanted) express his opinion. It was especially interesting in relation to the written works proposed by this methodologist: it is also themes of comparative character, in which students were encouraged to compare one work with the biography of its author, with his personality, or with epoch and culture, as well as making comparisons in the framework of characters of one or more works.

B. Golubkov (1880-1968) is a scientist who came into science as a methodologist who developed the basics of teaching literature. He wrote: «Method of a systematic comparison of literary phenomena is especially important for the history of literature as a study of human nature» (Golubkov, 1962: 268). And his article «Study of Literature in High School» was very popular in its time. In it, he noted that in high school, the main task of literature is to give students an idea of the historical and literary process and ways of development of literature. To achieve this, he suggested revealing the creative uniqueness of each writer by identifying his similarities or differences with other writers. For example, he suggested comparing writers who are close to each other by ideology and style (Griboyedov, Lermontov, Pushkin) and further comparing writers and works using contrast («What Is to Be Done?», «Fathers and Sons», «Crime and Punishment»). Thus, with the help of comparative linguistics, students come to conclusions about the evolution of writers and the development of literature in general.

The method of comparison, or comparative analysis, and its great importance for the methodology, is noted in the works of M. Rybnikova (18851942), V. Nikolsky (1875-1934), and N. Kudryasheva (1904-1981), N. Moldavskaya (1916-1978), N. Meshcheriakova (1865-1942), Z. Rez (1921-2009), L. Aizerman (1929), the writings of O. Bogdanov (1930-2007), V. Marantzman (1932-2007), V. Chertov (1954) and others.

It can thus be argued that the methods of comparative literature are recommended and used by many leading methodologists of both the past and the present, asserting the effectiveness of the method of comparison and collation. Many methodologists suggest using comparative linguistics when drawing parallels between literature and other arts, as well as comparing the heroes of one work because the heroes are always either compared by the author or opposed to each other. This helps to achieve a more comprehensive understanding of the literary writing's idea and a more complete interpretation.

Comparative linguistics as a method can be used in a variety of works. For example, one of the methods is comparing the work with its historical (real) basis, comparing the hero with his prototype. This method is interesting for the sake of allowing us to 
study not only the creative history of the work but also to understand the culture of the time when the work was written. Creative works that will interest students in this field can be extremely diverse. For example, when studying the writers of the XIX century, to pay attention to the culture of the time, fashion, etc.

Comparative linguistics as a method can be used in a variety of works. For example, one of the methods is collating the work with its historical (real) basis, comparing the hero with his prototype. This method is interesting for the sake of allowing us to study not only the creative history of the work but also to understand the culture of the time when the work was written. Creative works that will interest students in this field can be extremely diverse. For example, when studying the writers of the XIX century it is possible to pay attention to the various aspects of their writings such as culture at the time, fashion, etc.

Comparative linguistics can also be scoped by broader comparisons. Thus, it is possible to compare different writers of the same era. This gives an understanding of the uniqueness of both the author and the cultural epoch of an artwork. The most interesting is the comparison of different authors of the same epoch, but different cultures (countries). For example, at the turn of the XIX-XX centuries, one can observe an obvious growth of the mutual influence of Russian and Western European literature. Mutual influences of G. Flaubert and I. Turgenev can be observed, together with the influence of E. Zol's aesthetics on Russian "naturalists" such as A. Amfitiatriov, P. Boborykin, and others. Not less interesting is to survey the influence of the French "cursed"( Poète maudit) heritage on the formation of the aesthetics movement in Russian modernism.

The need to highlight such research in the course of teaching literature is dictated by the increasing mutual influence of cultures, the process of blurring the boundaries between national cultures and, consequently, their literature. And understandable is the opinion of Y. Whipper, who writes that "...without improving the method of comparative analysis, it is impossible to build a comprehensive history of art (at least within the limits of one epoch), not to mention the complete history of spiritual culture as a whole" (Whipper, 1990: 285).

A comparison of different critical articles about a single work provides great opportunities for analysis. On the one hand, it is a comparison of several interpretations, and on the other hand, it is a study of a critical attitude towards the writer. This type of comparison is of interest to modern teaching methods where the writer ceased to be a "teacher" for the reader as it was used to be before. This method of studying a literary work is very effective "when the work has a controversial history when the moral assessment of the hero depends on the choice of interpretation, and when certain elements of the work permit different interpretations" (Kiselev,1989:72).

Different critical articles usually have polar judgments on the same question. In this regard, the ability to compare and draw conclusions independently provides room different interpretations of the context of the work and making independent inferences through a variety of other people's interpretations. Often one changes the primary understanding of the text and forms a new perception while processing the literary works and analyzing the text of critical articles.

In the modern system of education, the most interesting type of comparison is when a literary work and other arts are compared. This strengthens empathy, the subjective side of the parse of a literary work, and also gives students a chance to give their interpretation of it by comparing with a theatrical production, film, opera, song, painting, and illustrations. This comparison is based on free associations, so it is the most complex and the most interesting.

For example, there is a huge number of different films (movies, TV and video fragments), created both on the basis of literary works and inspired by them. This is of interest for analyzing and comparing the film and the fiction in terms of interpretation, i.e. compiling different types of verbal information into a visual image that, when perceived, can be deployed and serve as a basis for appropriate thought and practical actions aimed at assimilating the learning material. Creative projects also have value, their essence being the analysis of a lyrical work and the independent selection of a video sequence and musical accompaniment to it.

As tasks that teach comparison, it is advisable to offer the following types of exercises that allow you to introduce elements of comparative analysis in each lesson (from simple to complex, from replication to compiling your own opinion or stance):

a) Speech exercises to teach written messages;

restore the beginning and end of the story: a) I am writing to learn more about...; b) I am writing to find out if I can...; c) I'm writing to ask..;

restore the dialogue on the individual "guiding" replicas: Please be so kind as to inform me when/if first; We thank you for this opportunity...;; 
a comparison chart drawing up by students:

intratext comparisons aimed at revealing the genre specifics of a work, the place and significance of genre inserts and genre syncretism

intertext comparisons, i.e. comparison of works of different genres belonging to the same or different kinds of literature;

interpretation comparisons or consideration of disputes about the genre of the work, the diversity of existing classifications of the genre system of literature in general and of individual genres in particular, social and ideological overacquisitions, the degree of dependence of artistic interpretation on the kind of literature (lyric poetry, painting and music; drama, painting and theater; prose, painting and cinema).

describe an ambiguous situation in various texts and dialogues, change the type of text (message to conversation, dialog to description): First of all I would like to get information about...; You are interested in..;
Explain the contradiction between text and illustrative information.;

b) written speech exercises for working with printed text (students gain access to LearningApps. org assignments (via qr-code). Up to 6 concept groups can be assigned in this activity. Inside the workspace, all elements are arranged chaotically. You need to define to which concept group each element belongs. If selected correctly, the part of the picture or video in the background will open.

c) comparison tests after reading the work (Kahoot).

d) a quiz based on character, work, author, literary direction (Mentimeter.com);

e) writing an essay on a topic based on comparison;

f) offering its interpretation of the work or the author's work as a whole (photo, video collage) to the work or presentation in the form of a historical and/or culturological commentary on the selected topic.

Taking into account the developments of V.Marantzman and other authoritative scientists, we can identify a working classification of comparative study of different kinds of literature.

\begin{tabular}{|c|c|c|}
\hline Comparison type & Place of work in the system & The objectives of the ongoing comparison \\
\hline $\begin{array}{l}\text { Comparison of an artwork with } \\
\text { the real story, of the hero with } \\
\text { the prototype. }\end{array}$ & $\begin{array}{l}\text { Studying the creative history } \\
\text { of the work. }\end{array}$ & $\begin{array}{c}\text { revealing the connection of the literary work to life; } \\
\text { detecting the author's intentions, comprehending the author's } \\
\text { intention by showing how the writer « aggravates» the material } \\
\text { taken from life. }\end{array}$ \\
\hline $\begin{array}{l}\text { Comparison of different } \\
\text { editions, text versions. }\end{array}$ & $\begin{array}{l}\text { Study of the creative history } \\
\text { of the work, analysis of the } \\
\text { work. }\end{array}$ & $\begin{array}{l}\text { Identifies the development of the author's thoughts in the } \\
\text { process of creating a work, develops artistic taste, develops strict } \\
\text { demands on their own style, bring up attention to the word. }\end{array}$ \\
\hline $\begin{array}{c}\text { Comparison of parts and } \\
\text { various elements of the art } \\
\text { text (comparison of images of } \\
\text { heroes, comparison of episodes, } \\
\text { consideration of the relationship } \\
\text { of landscape and portrait with } \\
\text { the general flow of the text). }\end{array}$ & $\begin{array}{l}\text { Analysis of composition, } \\
\text { study of questions of the } \\
\text { theory of literature. }\end{array}$ & $\begin{array}{l}\text { comprehension of the characters of the work; revealing the } \\
\text { author's position; revealing the writer's artistic method; } \\
\text { revealing the unity of form and content of a literary work; } \\
\text { strengthening the emotional reaction of schoolchildren. }\end{array}$ \\
\hline $\begin{array}{l}\text { Comparison of works by } \\
\text { different writers or individual } \\
\text { elements of artistic texts } \\
\text { (landscape, portrait) }\end{array}$ & $\begin{array}{c}\text { Composition analysis, idea } \\
\text { analysis. }\end{array}$ & $\begin{array}{l}\text { assimilation of ideological content, emphasizing the } \\
\text { commonality of moral conflict, artistic situation, helps to see } \\
\text { the «portrait» of the era and understand the originality of the } \\
\text { artistic world of each writer to clarify the regularities of the } \\
\text { literary process }\end{array}$ \\
\hline $\begin{array}{c}\text { Comparison of interpretations of } \\
\text { critical articles }\end{array}$ & $\begin{array}{l}\text { A complete analysis of the } \\
\text { work. }\end{array}$ & $\begin{array}{l}\text { Trains the ability to correlate the ideological and aesthetic position } \\
\text { of a critic with the interpretation of works presented by him, } \\
\text { stimulate secondary emotional perception and intellectual activity. }\end{array}$ \\
\hline $\begin{array}{l}\text { Comparison of this work with } \\
\text { other works by the writer }\end{array}$ & $\begin{array}{l}\text { Study of creative evolution, } \\
\text { idea and style analysis }\end{array}$ & $\begin{array}{l}\text { Conceptual perception of the work; the discovery of the general } \\
\text { foundations of worldview and artistic method, can show how } \\
\text { the artistic view of the world has changed. }\end{array}$ \\
\hline $\begin{array}{l}\text { Comparison of a literary work } \\
\text { with works of another kind of art }\end{array}$ & $\begin{array}{c}\text { Analysis of creative concept/ } \\
\text { plan, analysis of artistic } \\
\text { features, complex analysis of } \\
\text { the work. }\end{array}$ & $\begin{array}{l}\text { Development of imagination, associative relations, } \\
\text { strengthening of empathy, subjective side of parse, } \\
\text { emphasizing the originality of the writer's position, worldview, } \\
\text { comprehension of the objective meaning of the work. }\end{array}$ \\
\hline
\end{tabular}




\section{Conclusions}

For instance, one way of doing it is to select a poem by a certain author and select those photos (pictures) and music (video, audio resources) that correspond to its contents and, accordingly, the interpretation of the work. In our opinion, in this kind of format lies the future of teaching literature, when the material is given using excerpts from theatrical, opera and ballet productions, from films or listening to songs and romances based on poems by one or another poet. Such multimedia (the possibility of using didactic tools of multimedia) makes it possible to take advantage of hypertext over linear text.
The scrutiny of literature, which is based on the methods of comparative linguistics, introduces a person to the independent creative search, contributes to a critical view of a work, revealing common patterns of the unified literary and cultural process, the investigation of literary ties and relations in their historical conditioning. In this context, the words of an unknown scholar are right, when he wrote that "the more the circle of literary phenomena expands. both geographically and historically, the more obvious is the interconnection of these phenomena or, in any case, the need to study them in comparison, not separately, but in the general context of human creative activity" (Whipper, 1990:300).

\section{References}

1. Belinskiy V.G. (1953-1959) Literaturnye mechtaniya [Literary dreams] Full collection of works: 13 t. Moscow: USSR Academy of Sciences Publications, 562 p. (In Russian)

2. Zhanpeiss U.A. (2019) Russkii yazyk i literatura [Russian language and literature]. Textbook for 9th grade of general education school with non-Russian language of education. Almaty: Atamura Publishing House (In Russian)

3. Whipper Y.B. (1990) O nekotorykh teoreticheskikh problemakh istorii literatury [On some theoretical problems of the history of literature] Creative destinies and history (On Western European Literatures of XVI - first half of XIX centuries). Moscow: Art. lit., 318 p. (In Russian)

4. Galai K.N. (2013) Funlcii khudohestvennoi detail v proze I. Bunina I Gi de Mopassan (opyt tipologicheskogo sravneniya) [Functions of fictional detail in the prose of I. Bunin and Guy de Maupassant (Experience of Typological Comparison). Candidate of Sciences Thesis - Moscow. (In Russian)

5. Dudova L.V. (2002) Komparativistika v shkolnom kurse literatury (sravnitelnoe izuchenie russkoi i zarubezhnoi literatury v schkole) [Comparative linguistics in the school course of literature (comparative study of Russian and foreign literature at school)] materials of IV all-Russian scientific-practical conference of the Russian society of teachers of Russian language and literature. National research Lobachevsky state University of Nizhny Novgorod (Nizhny Novgorod), 88 p. (In Russian)

6. Golubkov V.V. (1962) Metody prepodavaniya literatury [Methods of teaching literature]. Moscow. Uchpedgiz Publishing House, 494 p. (In Russian)

7. Kiselev A. K. (1989) Sopostavlenie kak priem aktivizacii emocionalnogo vospriyatiya i intellektualnoi deyatelnosti starscheklassnikov v literaturnom obrazovanii [Collation as a method of activation of emotional perception and intellectual activity of high school students in literary education]. Synopsis of the Cand. of Ped. sciences thesis. Moscow, 72 p. (In Russian)

8. Marantzman, V.G. (1908) Metody i priemy analiza literaturnogo proizvedeniya v schkole [Methods and methods of the literary work analysis at school] Methods of teaching literature: Textbook for pedagogical higher education institutions / Under edition of O.Y. Marantzman published in 2 parts. Part 1, Moscow (In Russian)

9. Stoyunin V.A. (1908) O prepodavanii russkoi literatury [About teaching Russian literature]. St. Petersburg, [Internet source], URL: http://elib.gnpbu.ru/text/stoyunin_o-prepodavanii-russkoy-literatury_1898. (In Russian)

10. Zhanpeiss U.A. (2018) Russkii yazyk i literatura [Russian language and literature] Methodical Guide: For teachers of 8th grade of secondary school with Kazakh as a teaching language. - Almaty: Atamura Publishing House, 411 p. (In Russian)

\section{Литература}

1. Белинский В.Г. Литературные мечтания // Полное собрание сочинений: В 13т. - М.: Изд. АН СССР, 1953-1959. - T.І. - 562 с..

2. Дудова Л.В. Компаративистика в школьном курсе литературы (сравнительное изучение русской и зарубежной литературы в школе) // материалы IV Всероссийской научно-практической конференции Российского общества преподавателей русского языка и литературы. Национальный исследовательский Нижегородский государственный университет им. Н.И. Лобачевского (Нижний Новгород). 2002. С. 88-89

3. Галай К.Н. Функции художественной детали в прозе И.Бунина и Ги де Мопассана (опыт типологического сравнения). Дис. ...канд.филол. наук. - М., 2013

4. Голубков В.В. Методы преподавания литературы. - М.: Учпедгиз, 1962. 494 с.

5. Киселев А. К. Сопоставление как прием активизации эмоционального восприятия и интеллектуальной деятельности старшеклассников в литературном образовании. Автореф. дис. ... канд. пед. наук.-М.,1989. с. 72

6. Маранцман В.Г. Методы и приемы анализа литературного произведения в школе // Методика преподавания литературы: Учебник для пед.вузов./ Под ред. Богдановой О.Ю.., Марнцмана В.Г. - В 2ч. Ч.1. - М., 1995.

7. Стоюнин В.А. О преподавании русской литературы. СПб, 1908. [Электронный pecypc], URL: http://elib.gnpbu.ru/ text/stoyunin_o-prepodavanii-russkoy-literatury_1898

8. Виппер Ю.Б. О некоторых теоретических проблемах истории литературы// Творческие судьбы и история (О западноевропейских литературах XVI - первой половины XIX века). - М.: Худож.лит., 1990. - 318 с.

9. Жанпейс У.А. Русский язык и литература. Методическое руководство: Для учителей 8 кл. общеобразоват. шк. с каз. яз. обучения/У.А. Жанпейс, Н.А. Озекбаева, Г.А. Атембаева. - Алматы: Атамұра, 2018. - 411 с.

10. Жанпейс У.А. Русский язык и литература. Учебник для 9 класса общеобразовательной школы с русским языком обучения. Алматы: Атамұра, 2019. 